\title{
Role of Dipeptidyl Peptidase-4 Inhibitor in the Control of Glycemic State in Type I and Type II Diabetes Mellitus in Rats: A Comparative Study
}

\author{
SOHAIR A. SALEH, M.D.; GERGESS S.Y. HANNA, M.D.; AHMAD M.M. GAAFAR, M.D.; \\ OMNIA A. ABD EL-MAABOUD, M.D. and EBTEHAL M.M. METWALLY, M.Sc. \\ The Department of Medical Physiology, Faculty of Medicine, Menoufia University, Egypt
}

\begin{abstract}
Background: Incretin hormones; glucose-dependent insulinotropic polypeptide (GIP) and glucagon-like peptide-1 (GLP-1) have attracted considerable scientific and clinical interest due largely to their insulin-releasing and glucoselowering properties. Dipeptidyl peptidase-4 (DPP-4) is the enzyme responsible for cleavage and inactivation of GIP and GLP-1.
\end{abstract}

Aim of Study: The present investigation was assigned to study and compare the effect of DPP-4 inhibitor (vildagliptin) on glycemic state in type I and type II diabetes mellitus in rats.

Material and Methods: Fifty male albino rats of local strain were used. Rats were divided into three groups: Nondiabetic (10 rats); type I diabetic (non-treated, 10 rats and Vildagliptin-treated, 10 rats); type II diabetic (non-treated group, 10 rats and Vildagliptin-treated, 10 rats). Type I diabetes was induced by a single intraperitoneal injection $(60 \mathrm{mg} / \mathrm{kg})$ of STZ dissolved in $0.2 \mathrm{ml}$ citrate buffer in adult 6 weeks old rats. $48 \mathrm{~h}$ later fasting blood samples were taken from rat tail and rats with fasting blood glucose levels greater than $250 \mathrm{mg} / \mathrm{d}$ were considered diabetic type I. They were left for 30 days before assessment. Type II diabetes was induced by a single intra-peritoneal injection $(90 \mathrm{mg} / \mathrm{kg})$ of STZ to a group of 2 days old pups. 6 weeks later, fasting blood samples were taken from rat tail and rats with fasting blood glucose level $\geq 160 \mathrm{mg} / \mathrm{dl}$ were considered as diabetic type II, they were left for 30 days before assessment. In both treated groups rats were treated daily with Vildagliptin $(5 \mathrm{mg} / \mathrm{kg})$ by oral gavage for 30 days. At the end of the experiment, retro-orbital fasting blood sample was taken for measurement of serum glucose, serum insulin, glycated hemoglobin (HbAlc), plasma GLP1 levels, lipid profile, malondialdehyde and total antioxidant capacity. Homeostasis model assessment of insulin resistance (HOMA-IR) index was calculated.

Results: Serum glucose, blood HbA1c, serum cholesterol, triglycerides (TG), low density lipoprotein-cholesterol (LDLcholesterol) and malondialdehyde (MDA) were significantly higher in type I and type II diabetic non-treated groups when

Correspondence to: Dr. Sohair A. Saleh, The Department of Medical Physiology, Faculty of Medicine, Menoufia University, Egypt compared to corresponding values in non- diabetic group. All the previous parameters were significantly lower in diabetic type I and type II vildagliptin-treated groups when compared to corresponding values in non-treated groups and the same parameters were significantly lower in type II Vildagliptintreated group when compared to corresponding values in type I vildagliptin-treated group. Serum insulin, high density lipoproteins (HDL-cholesterol) and total antioxidant capacity (TAC) in type I and type II diabetic non-treated groups were significantly lower when compared to corresponding values in non-diabetic group, while all the previous parameters were significantly higher in type I and type II Vildagliptin-treated groups when compared to corresponding values in type I and type II diabetic non-treated groups. The same parameters were significantly higher in type II Vildagliptin-treated group when compared to corresponding values in type I vildagliptin treated group. There was insignificant change in HOMA-IR and plasma GLP-1 level in type I diabetic (both non-treated and Vildagliptin-treated) groups when compared to corresponding values in non-diabetic group; on the other hand HOMA-IR was significantly higher while plasma GLP-1 level was significantly lower in type II diabetic non- treated group when compared to corresponding values in non-diabetic group. In type II diabetic Vildagliptin-treated group HOMA-IR was significantly lower while plasma GLP-1 level was significantly higher when compared to corresponding values in non-treated group. Upon comparing type I and type II non-treated groups; serum glucose, HbA1c and plasma GLP-1 were significantly higher while serum insulin and HOMA-IR were significantly lower in type I non-treated group when compared to corresponding values in type II non-treated group. On the other hand there was insignificant difference in all other parameters between the two groups.

Conclusion: Vildagliptin treatment is a good choice for type II diabetes treatment and has beneficial effects in type I diabetes.

Key Words: DPP-4 - Type I diabetes mellitus - Type II diabetes mellitus - Rats.

\section{Introduction}

DIABETES mellitus is a complex, chronic disease characterized by high blood glucose levels that result from defects in either insulin secretion, action, or both [1]. Diabetes mellitus was classified 
into type I, type II, Gestational and Other types of diabetes mellitus [1]. Both insulin deficiency and insulin resistance promote dyslipidemia accompanied by increased oxidation, glycosylation, and triglyceride enrichment of lipoproteins [2]. Lipid abnormalities might play a role in the pathogenesis of the complications in diabetes [3]. Diabetesinduced hyperglycaemia is now recognized to result in oxidative stress [4]. GIP and GLP-1 are gastrointestinal hormones that potentiate glucose stimulated insulin secretion and are known as incretin hormones. These incretins stimulate both insulin biosynthesis and proliferation of $\beta$-cells while inhibiting apoptosis [5]. Dipeptidyl peptidase-4 (DPP4) is a glycoprotein peptidase responsible for the inactivation of a number of hormones and peptides including the incretin hormones, substance $\mathrm{P}$, and chemokines [6-7]. Vildagliptin is a potent and selective inhibitor of dipeptidyl peptidase-4 (DPP4), which extends the physiological effects of GLP1 and GIP resulting in improvement of glycemic control in a glucose-sensitive manner [8]. The present investigation was conducted to detect and compare the effects of DPP-4 inhibitor (vildagliptin) on glycemic state in type I and type II diabetes mellitus in rats.

\section{Patients and Methods}

The present study was conducted between September 2017 and January 2018 in Medical Physiology Department, Faculty of Medicine, Menoufia University, Egypt. It was approved by the Research Ethics Committee at Faculty of Medicine, Menoufia University.

\section{Experimental animals:}

Fifty male albino rats of local strain were used in this investigation. Rats were housed in standard conditions with a natural light-dark cycle and were caged in a wire mesh ventilated cages with free access to food and water throughout the study period. Rats were divided into three groups:

1- Non-diabetic group (10 rats): In this group 6 weeks old normal rats were treated with vehicle (single intraperitoneal injection of $0.2 \mathrm{ml}$ citrate buffer) only and left for 30 days before assesment.

2- Type I diabetic (Type I DM) group (20 rats): rats of this group were rendered diabetic type I by single intraperitoneal injection $(60 \mathrm{mg} / \mathrm{kg})$ of STZ dissolved in $0.2 \mathrm{ml}$ citrate buffer $(10 \mathrm{mM}$ citrate buffer, $\mathrm{pH} 4.5$ ) to adult 6 weeks old rats. $48 \mathrm{~h}$ later rats with fasting blood glucose levels greater than $250 \mathrm{mg} / \mathrm{dl}$ in a rat tail venous blood sample were considered diabetic type I [9]. Diabetic type I rats were further subdivided into two subgroups: a- Type I DM non-treated group (10 rats): After being diabetic type I, rats of this group were left for 30 days before assessment.

b- Type I DM Vildagliptin-treated (Vil-treated) group (10 rats): After being diabetic type I, rats of this group were treated with Vildagliptin $(5 \mathrm{mg} / \mathrm{kg})$ by oral gavage for 30 days [10]

3- Type II diabetic (Type II DM) group (20 rats): Rats of this group were rendered diabetic type II by a single intraperitoneal injection $(90 \mathrm{mg} /$ $\mathrm{kg}$ ) of STZ to a group of 2 days old pups then 6 weeks after the injection of STZ, the animals were checked for fasting glucose level in a rat tail venous blood sample, rats with fasting blood glucose $>160 \mathrm{mg} / \mathrm{dl}$ were considered as diabetic type II [11] Diabetic type II rats were further subdivided into two subgroups:

a- Type II DM non-treated group (10 rats): After being diabetic type II, rats of this group were left for 30 days before assessment.

b- Type II DM Vildagliptin-treated (Vil- treated) group (10 rats): After being diabetic type II, rats of this group were treated with Vildagliptin $(5 \mathrm{mg} / \mathrm{kg})$ by oral gavage for 30 days [10]

At the end of experimental period fasting blood samples were taken for measurement of:

Serum glucose [12], serum insulin [13], glycated hemoglobin (HbA1c) [14], plasma bioactive GLP1 levels [15], lipid profile [16-19], malondialdehyde [20-21] and total antioxidant capacity [22]. Homeostasis model assessment of insulin resistance (HOMA-IR) index was calculated [23]

\section{Chemicals:}

Streptozotocin (STZ) (Sigma-Aldrich Chemical Co, USA). Kits for estimation of serum MDA (Biodiagnostic Company, Egypt). Kits for estimation of total antioxidant capacity TAC (Biodiagnostic Company, Egypt). Kits for estimation of serum glucose and HbA1c (Biodiagnostic Company, Egypt). Citrate buffer 10mmol/L, pH 4.5 (Biodiagnostic Company, Egypt). Kits for estimation of insulin (DRG Instruments GmbH, Germany). Kits for estimation of active Glucagon-like peptide-1 (7-36) ELISA (IBL International GmbH, Germany). Kits for estimation of fasting serum lipid profile (Biodiagnostic Company, Egypt).

\section{Blood sampling:}

$4 \mathrm{ml}$ of fasting blood was collected from the retro-orbital venous plexus, using a fine heparinized capillary tube introduced into the medial epicanthus of the rat's eye [24]. They were devided into two test tubes: 
- For serum separation $2 \mathrm{ml}$ of blood were collected in a clean graduated centrifuge tube, left for clotting at room temperature in a water bath for 10 minutes, and then centrifuged at 3000r.p.m (rotation per minute) for 20 minutes. The supernatant serum was collected in a dry clean tube for analysis of serum glucose and insulin levels, serum lipid profile serum malondialdehyde and total antioxidant capacity and HOMA-IR index.

- For whole blood and plasma separation the other $2 \mathrm{ml}$ of blood were collected into EDTA-treated tubes for assessment of Glycated hemoglobin (HbA1c) and plasma active glucagon like peptide1 (GLP-1) respectively.

\section{Statistical analysis:}

The SPSS version 16 (SPSS Inc., Chicago, IL, USA) was used for analysis of data. The results were expressed as mean \pm the standard error of mean (S.E.M). The significance of differences between groups was determined by one-way analysis of variance (ANOVA) and post-hoc Tukey test was done. $p$-values $\leq 0.05$ were considered statistically significant.

\section{Results}

Fig. (1) illustrates the means \pm S.E.M of serum glucose and $\mathrm{HbA} 1 \mathrm{c}$ in the different experimental groups.

This figure shows that: Fasting serum glucose and HbA1c of type I DM and Type II DM (both non-treated and Vil-treated) groups were significantly higher when compared to corresponding values of non-diabetic group. Fasting serum glucose and $\mathrm{HbA} 1 \mathrm{c}$ of type I DM Vil-treated group showed insignificant change when compared to corresponding values of type I non-treated group. But they were significantly lower in type II diabetic Viltreated group when compared to corresponding values in type II diabetic non-treated group. Fasting serum glucose and HbA1 c of type II DM (both non-treated and Vil-treated) groups were significantly lower when compared to corresponding values of type I DM (both non-treated and Vildagliptin-treated) groups respectively.

Fig. (2) illustrates the means \pm S.E.M of serum insulin and HOMA-IR in the different experimental groups.

Serum insulin level of type I and Type II diabetic groups (both non-treated and Vildagliptin-treated) was significantly lower when compared to corresponding value of non-diabetic group. Serum insulin level of type I diabetic Vil-treated group showed insignificant change when compared to corresponding value of non-treated group; but it was significantly higher in type II diabetic Viltreated one when compared to corresponding value in type II diabetic non-treated group. Serum insulin level of type II diabetic groups (both non-treated and Vil-treated) was significantly higher when compared to corresponding values of type I DM (both non-treated and Vil-treated) groups respectively.

HOMA-IR index of type I diabetic (both nontreated and Vildagliptin-treated) groups showed insignificant change when compared to corresponding values of non-diabetic group. On the other hand, HOMA-IR index of Type II diabetic (both non-treated and Vil-treated) groups was significantly higher when compared to corresponding values of non-diabetic group. HOMA-IR index of type I diabetic Vil-treated group showed insignificant change when compared to corresponding value of non-treated group; while it was significantly lower in type II diabetic Vil-treated group when compared to corresponding value in type II non-treated group. HOMA-IR index of type II diabetic (both non-treated and Vildagliptin-treated) groups was significantly higher when compared to corresponding values of type I DM (both nontreated and Vildagliptin-treated) groups respectively.

Table (1) shows plasma bioactive GLP-1 of the different experimental groups.

Plasma bioactive GLP-1 (7-36) level of type I diabetic groups (both non-treated and vil-treated) showed insignificant change when compared to corresponding value of non-diabetic group. On the other hand Plasma bioactive GLP- 1 (7-36) level of Type II diabetic non-treated group was significantly lower when compared to corresponding value of non-diabetic group; while in type II Viltreated group it was insignificantly different when compared to corresponding value of non-diabetic group. Plasma bioactive GLP- 1 (7-36) level of both type I and type II diabetic Vil-treated groups were significantly higher when compared to corresponding values of non-treated groups. Plasma bioactive GLP-1 (7-36) level of type II diabetic (both non-treated and vildagliptin-treated groups) were significantly lower when compared to corresponding values of type I diabetic (both non-treated and Vildagliptin-treated groups).

Table (2) shows serum total cholesterol, triglycerides (TG), low-density lipoprotein-cholesterol (LDL-cholesterol) and high-density lipoprotein- 
cholesterol (HDL-cholesterol) in the different experimental groups.

Serum total cholesterol, TG and LDL-cholesterol were significantly higher while HDLcholesterol was significantly lower in type I and Type II DM groups (both non-treated and Viltreated) when compared to corresponding values of non-diabetic group. Serum total cholesterol, TG and LDL-cholesterol were significantly lower while HDL-cholesterol was significantly higher in type I and type II diabetic Vil-treated groups when compared to corresponding values of non- treated groups. Serum total cholesterol, TG, LDL-cholesterol and HDL-cholesterol of type II diabetic non-treated group were insignificantly different when compared to type I diabetic non- treated group; on the other hand in type II diabetic Viltreated group serum total cholesterol, TG and LDLcholesterol were significantly lower while HDLcholesterol was significantly higher when compared to corresponding values of type I diabetic Viltreated group.
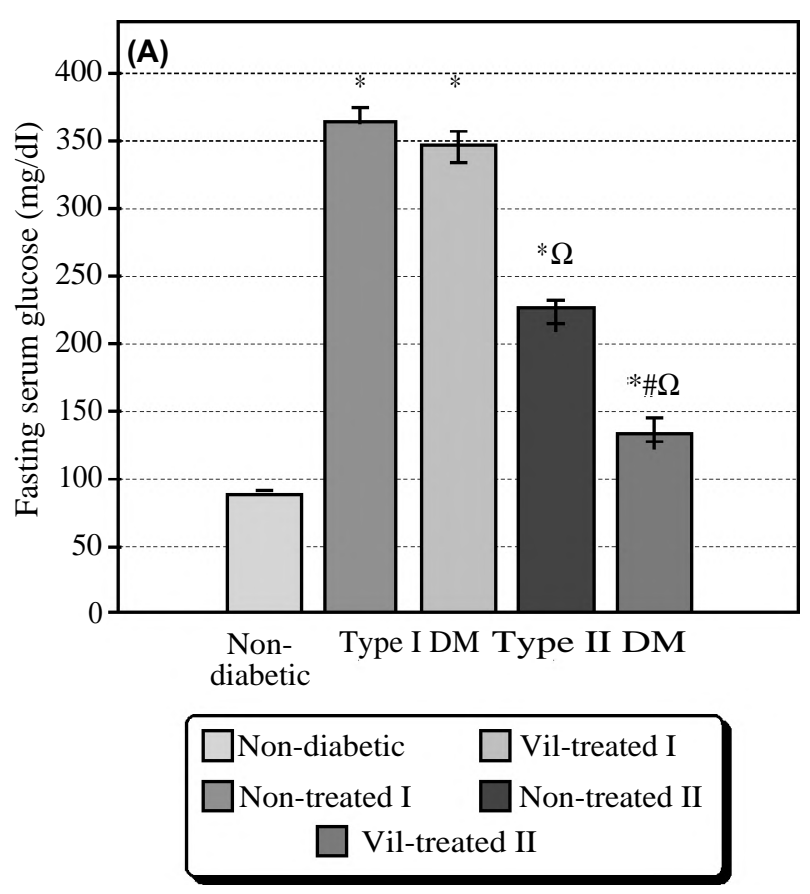

Fig. (3) illustrates the means \pm S.E.M of Serum MDA and TAC in the different experimental groups.

Serum MDA of type I and Type II DM (both non-treated and Vil-treated) groups were significantly higher when compared to corresponding values of non-diabetic group. On the other hand Serum TAC of type I and Type II DM (both nontreated and Vil-treated) groups were significantly lower when compared to corresponding values of non-diabetic group. Serum MDA of type I and type II diabetic Vildagliptin-treated groups showed significantly lower levels when compared to corresponding values of non-treated groups in contrast to serum TAC which showed significantly higher level. Serum MDA and TAC of type II diabetic non-treated group were insignificantly different when compared to type I diabetic non-treated group; on the other hand in type II diabetic Viltreated group serum MDA showed significantly lower level when compared to corresponding value of type I diabetic Vil-treated group, but serum TAC showed significantly higher level between the two groups.
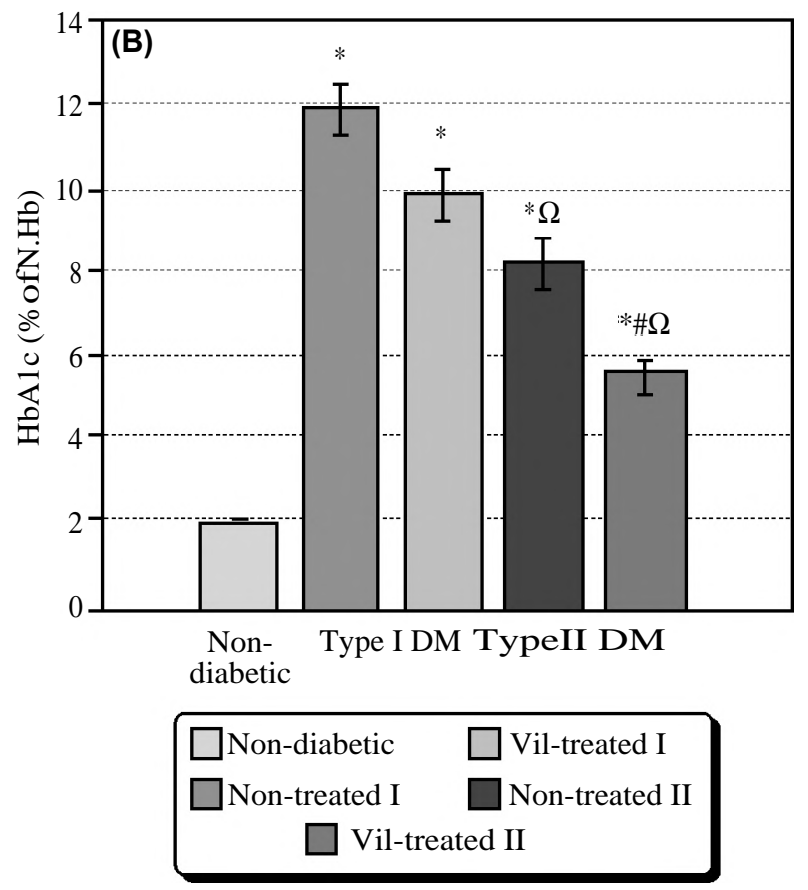

Fig. (1): Serum glucose (panel A) and HbAlc (\% of N.Hb) (panel B) in Non-diabetic, type I diabetic (non-treated and vildagliptin-treated) and type II diabetic (non-treated and vildagliptin-treated) rats $\emptyset$.

\footnotetext{
$\emptyset:$ The number of rats in each group was 10.

$p$-value $\leq 0.05$ is considered significant.

* : Significant whin compared to corresponding value in non-diabetic groups.

\# : Significant whin compared to corresponding values in diabetic non-treated groups.

$\Omega$ : Significant whin compared to corresponding values in type I DM groups.
} 

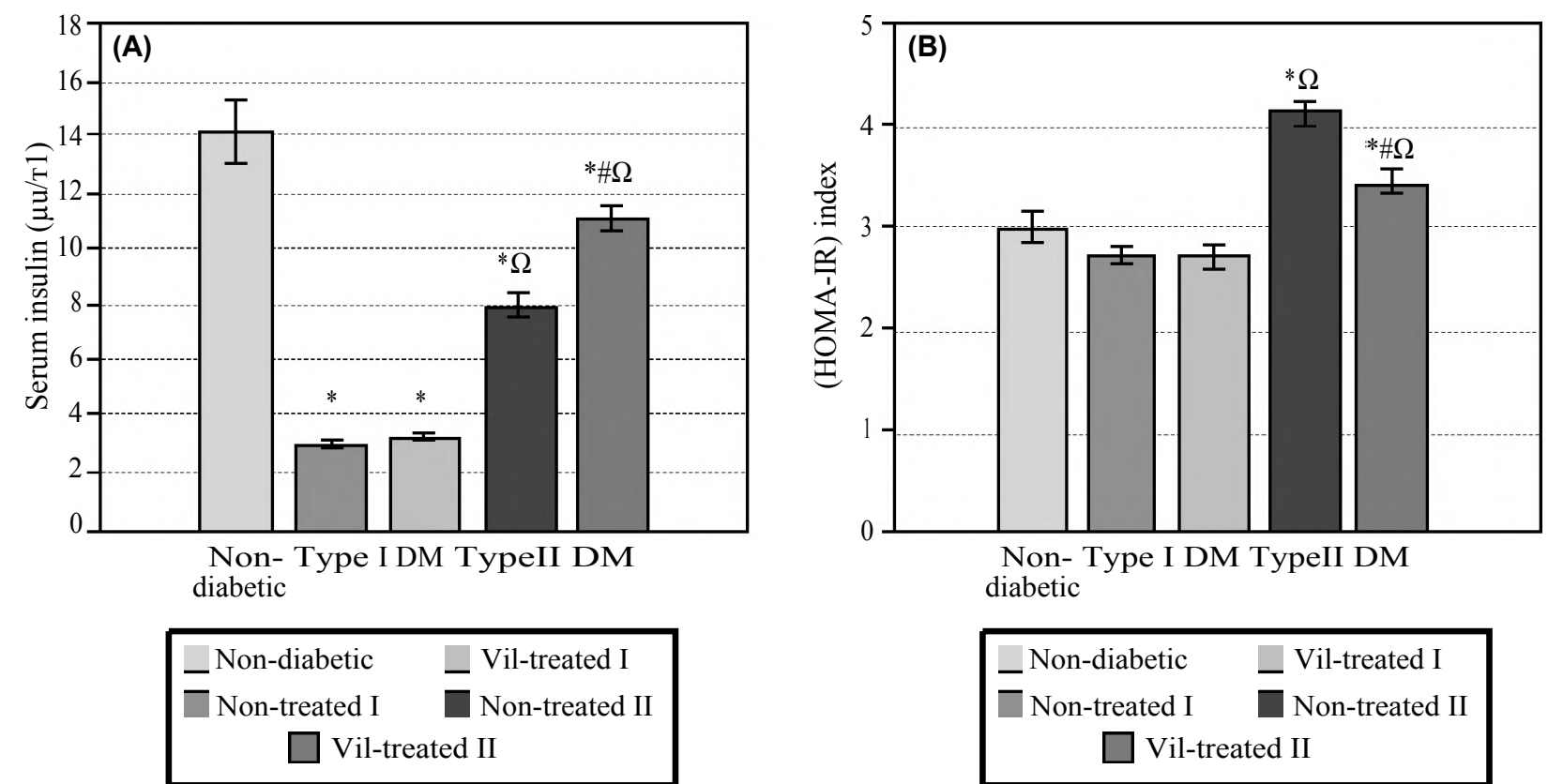

Fig. (2): Serum insulin (panel A) and HOMA-IR index (panel B) in Non-diabetic, type I diabetic (non-treated and vildagliptin-treated) and type II diabetic (non-treated and vildagliptin-treated) rats ø.
ø: The number of rats in each group was 10 .
$p$-value $\leq 0.05$ is considered significant.
* : Significant when compared to corresponding value in non-diabetic groups.
\# : Significant when compared to corresponding values in diabetic non-treated groups.
$\Omega$ : Significant when compared to corresponding values in type I DM groups.
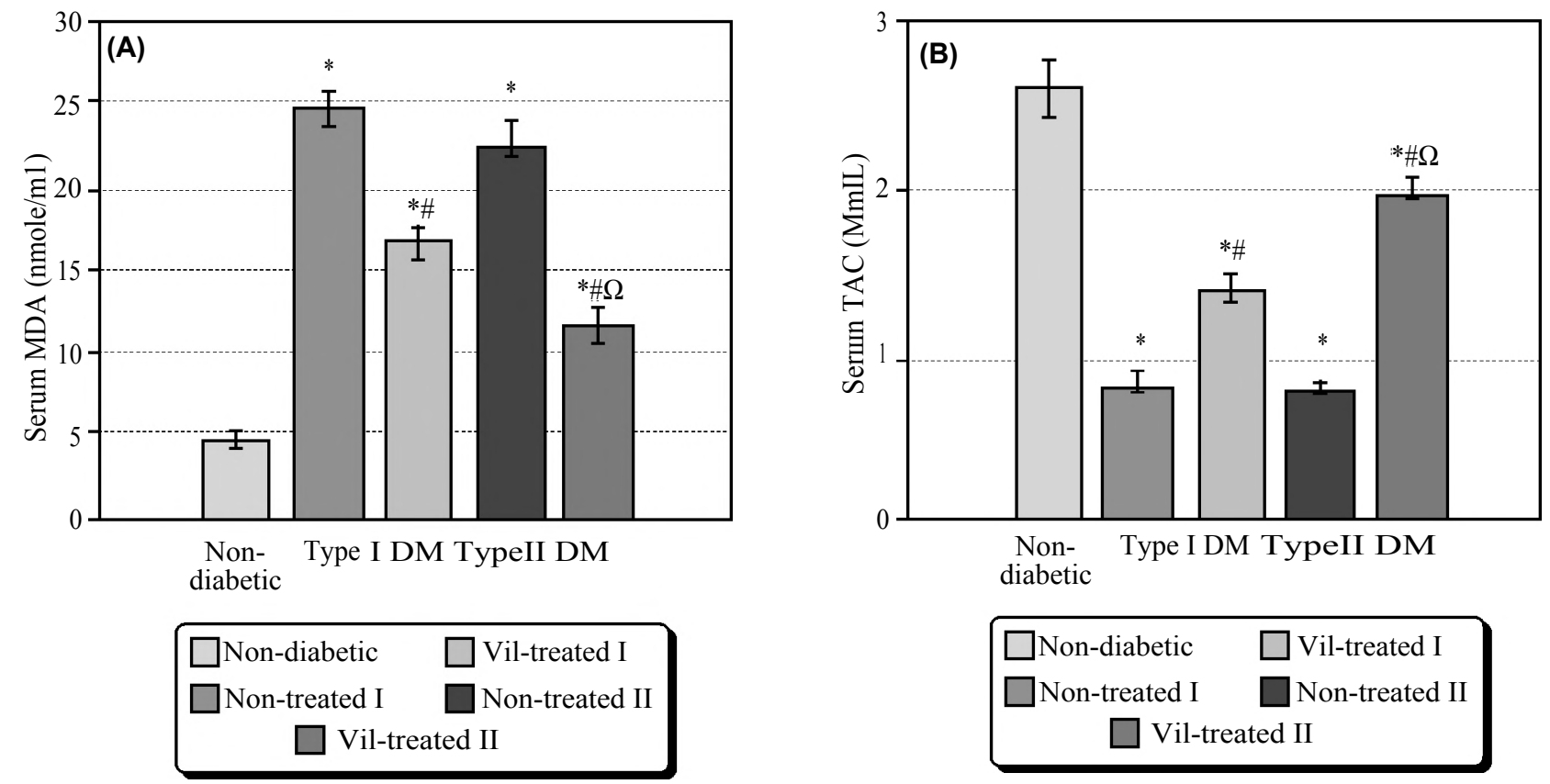

Fig. (3): Serum MDA (nmole/ml) (panel A) and Tac $(\mathrm{Mm} / \mathrm{L})$ (panel B) in type I diabetic (non-treated and vildagliptintreated) and type II diabetic (non-treated and vildagliptin-treated) rats $ø$.

\footnotetext{
$ø:$ The number of rats in each group was 10

$p$-value $\leq 0.05$ is considered significant.

* : Significant when compared to corresponding value in non-diabetic groups.

\# : Significant when compared to corresponding values in diabetic non-treated groups.

$\Omega$ : Significant when compared to corresponding values in type I DM groups.
} 
Table (1): Plasma bioactive GLP-1(7-36) level in non-treated type I diabetic (non-treated and vil-treated) and type II diabetic (non-treated and vil-treated) rats $\emptyset$.

\begin{tabular}{|c|c|c|c|c|c|}
\hline \multirow{2}{*}{$\begin{array}{l}\text { Group } \\
\text { Parameter }\end{array}$} & \multirow{2}{*}{$\begin{array}{l}\text { Non- } \\
\text { diabetic }\end{array}$} & \multicolumn{2}{|c|}{ Type I DM } & \multicolumn{2}{|c|}{ Type II DM } \\
\hline & & $\begin{array}{l}\text { Non- } \\
\text { treated }\end{array}$ & $\begin{array}{c}\text { Vil- } \\
\text { treated }\end{array}$ & $\begin{array}{l}\text { Non- } \\
\text { treated }\end{array}$ & $\begin{array}{c}\text { Vil- } \\
\text { treated }\end{array}$ \\
\hline GLP-1(7-36) level Pmol/1 & $11.7 \pm 0.87$ & $9.9 \pm 1.1$ & $14.2 \pm 1.2$ & $3.6 \pm .54$ & $9.7 \pm .84$ \\
\hline$p_{1}$ value & & $>0.05$ & $>0.05$ & $>0.001$ & $>0.05$ \\
\hline$p 2$ value & & & $<0.05$ & & $<0.001$ \\
\hline$p_{3}$ value & & & & $<0.001$ & $<0.05$ \\
\hline
\end{tabular}

Table (2): Serum total cholesterol, triglycerides (TG), low-density lipoprotein-cholesterol (LDL-cholesterol) and high-density lipoprotein-cholesterol (HDL-cholesterol) in non-diabetic type I diabetic (nontreated and vil-treated) and type II diabetic (non-treated and vil-treated) rats $\emptyset$.

\begin{tabular}{|c|c|c|c|c|c|}
\hline \multirow[b]{2}{*}{ Parameter } & \multirow{2}{*}{$\begin{array}{l}\text { Non- } \\
\text { diabetic }\end{array}$} & \multicolumn{2}{|c|}{ Type I DM } & \multicolumn{2}{|c|}{ Type II DM } \\
\hline & & $\begin{array}{l}\text { Non- } \\
\text { treated }\end{array}$ & $\begin{array}{l}\text { Vil- } \\
\text { treated }\end{array}$ & $\begin{array}{l}\text { Non- } \\
\text { treated }\end{array}$ & $\begin{array}{l}\text { Vil- } \\
\text { treated }\end{array}$ \\
\hline $\begin{array}{l}\text { Total cholesterol }(\mathrm{mg} / \mathrm{dI}) \\
p_{1} \text { value } \\
p_{2} \text { value } \\
p_{3} \text { value }\end{array}$ & $89 \pm 2.46$ & $\begin{array}{l}135.5 \pm 3.86 \\
<0.001\end{array}$ & $\begin{array}{l}118.2 \pm 2.21 \\
<0.001 \\
<0.001\end{array}$ & $\begin{array}{l}125.6 \pm 2.81 \\
<0.001 \\
>0.05\end{array}$ & $\begin{array}{l}102.88 \pm 1.53 \\
<0.05 \\
<0.001 \\
<0.05\end{array}$ \\
\hline $\begin{array}{l}(\mathrm{TG})(\mathrm{mg} / \mathrm{dI}) \\
p_{1} \text { value } \\
p^{2} \text { value } \\
p_{3} \text { value }\end{array}$ & $59.3 \pm 1.7$ & $\begin{array}{l}92.67 \pm 2.02 \\
<0.001\end{array}$ & $\begin{array}{l}82.57 \pm 2.09 \\
<0.001 \\
<0.05\end{array}$ & $\begin{array}{l}91.84 \pm 2.04 \\
<0.001 \\
>0.05\end{array}$ & $\begin{array}{l}71.61 \pm 2.03 \\
0.001 \\
<0.001 \\
<0.05\end{array}$ \\
\hline $\begin{array}{l}\text { LDL-cholesterol }(\mathrm{mg} / \mathrm{dI}) \\
p_{1} \text { value } \\
p^{2} \text { value } \\
p_{3} \text { value }\end{array}$ & $49.1 \pm 1.94$ & $\begin{array}{l}85 \pm 1.42 \\
<0.001\end{array}$ & $\begin{array}{l}72.79 \pm 1.2 \\
<0.001 \\
<0.001\end{array}$ & $\begin{array}{l}82.32 \pm 1.56 \\
<0.001 \\
>0.05\end{array}$ & $\begin{array}{l}64.01 \pm 1.21 \\
<0.001 \\
<0.001 \\
0.001\end{array}$ \\
\hline $\begin{array}{l}\text { HDL-cholesterol }(\mathrm{mg} / \mathrm{dI}) \\
p_{1} \text { value } \\
p_{2} \text { value } \\
p_{3} \text { value }\end{array}$ & $37.66 \pm 1.48$ & $\begin{array}{l}18.6 \pm 1.13 \\
<0.001\end{array}$ & $\begin{array}{l}25.5 \pm 1.28 \\
<0.001 \\
<0.05\end{array}$ & $\begin{array}{l}19.7 \pm 1.22 \\
<0.001 \\
>0.05\end{array}$ & $\begin{array}{l}31.37 \pm 1.47 \\
<0.05 \\
<0.001 \\
<0.05\end{array}$ \\
\hline
\end{tabular}

\section{Discussion}

\section{Diabetic non-treated groups (Type I and type II):}

In the present work type I and type II diabetes were experimentally induced by a single intraperitoneal injection of STZ when a dose of $60 \mathrm{mg} /$ $\mathrm{kg}$ was injected in adult rats, it produced type I DM while in a dose of $90 \mathrm{mg} / \mathrm{kg}$ in 2 days old pups it produced type II DM [25]. proved the usefulness of the STZ-diabetic rat as a model that reliably have many of the major clinical, biochemical, and hematologic features of type 1 human DM. [26] reported that rats injected with STZ at neonatal stage (n-STZ) exhibit decreased $\beta$-cell mass and develop features (hyperglycemia, polyphagia, polydipsia, polyuria and insulin resistance) in adulthood that closely resemble type 2 DM patients. Supporting the previous studies, our investigation showed that both type I and type II diabetic non-treated rats developed a significant increase in serum glucose level when compared to corresponding values in non-diabetic group and the hyperglycemia was significantly higher in type I when compared to type II non-treated group, these findings agree with [27]. In both previously mentioned groups HbA1c was significantly increased when compared to corresponding values in non-diabetic group and it was significantly higher in type I non-treated 
group when compared to corresponding value of type II non-treated group a finding which can be explained by the level of hyper-glycemia in each group. Similar results were reported by [28]

Regarding serum insulin level in type I and type II diabetic non-treated rats it was significantly lower when compared to corresponding values in non-diabetic group and it was significantly lower in type I non-treated group when compared to corresponding value of type II non-treated group. [29] reported that in adult rats, $60 \mathrm{mg} / \mathrm{kg}$ dose of STZ induce insulin dependent diabetes causing massive $\beta$-cell necrosis. On the other hand, [30] reported that at 6-15 weeks after single dose administration to neonatal rats, STZ induces $\beta$-cell injury with limited regeneration. Based on these studies the difference in the magnitude of $\beta$-cell distruction in each of our diabetic models can explain the significant difference in serum insulin level between the non-treated diabetic groups and certainly its significant decrease in both diabetic groups when compared to the non-diabetic one.

We also found that plasma bioactive GLP-1 (736) level was insignificantly changed in type I diabetic non-treated group when compared to corresponding value in non-diabetic group. this result agrees with [31] who found that although the level of the incretin hormones GLP- 1 and GIP were normal in type I diabetic patients, the degree of augmented insulin secretion during oral glucose ingestion is below normal in these patients. On the other hand, plasma bioactive GLP-1 (7-36) level was significantly decreased in type II diabetic nontreated group when compared to corresponding value in non-diabetic group. This result agrees with [32] . studies concerning GLP- 1 secretion in patients with type 2 diabetes have observed both unaltered [33] and reduced [34] GLP-1 responses, suggesting a varying GLP- 1 -secreting profile during the development and progression of type 2 diabetes $[33,34]$ or difference in the measurement technique [35]. This is further supported by the observation that several factors (BMI, glucagon, age, and nonesterified fatty acids, including medications, influence the secretion of GLP- 1 [36]. A significant impairment of the secretion of GLP-1 was observed in type II diabetes and the impairment was found to be related to impaired $\beta$-cell function. A reduced incretin effect is seen only in those patients with chronic pancreatitis, who also develop diabetes, but not in those who have normal glucose tolerance. This observation probably indicate that the impaired secretion is a consequence rather than a cause of diabetes [37].
We also detected significantly elevated levels of serum total cholesterol, TGs and LDL while significantly lower level of HDL in type I and type II diabetic non-treated groups when compared to corresponding values in non-diabetic group, similar results were reported by [38-39]. HDL especially plays an important role by accepting cholesterol, phospholipids and apoproteins that are released during degradation of triglycerides. Its concentration is regulated by an insulin dependent enzyme lipoprotein lipase (LPL). Hence inadequate availability of insulin decreases the enzyme LPL and may contribute to the lowering of serum HDL by increase removal of HDL cholesterol from blood of diabetic animals [40]. Insulin resistance may be a direct cause of decrease of HDL concentration; furthermore the markedly increased level of triglycerides and LDL-cholesterol in the serum of diabetic rats of the present work may be a consequence of either overproduction by the liver or defective removal from the circulation or both secondary to insulin deficiency [41].

In our investigation a significantly higher level of serum MDA and lower TAC in both diabetic non-treated groups when compared to the nondiabetic group was detected. Similar results were reported by [42] who reported significant increase in plasma MDA level in a high fed diet type II diabetic rats when compared to the non-diabetics and [43] who demonstrated elevated MDA levels as an indicator of oxidative stress in different tissues of both type I and type II diabetic models with insignificant difference between the two diabetic groups. Hyperglycemia which can explain the developed oxidative stress in our diabetic models is a factor shared by both type I and type II diabetics, is a major contributor to oxidative stress either by the direct generation of ROS or by altering the redox balance. This is thought to occur via several well studied mechanisms, including increased intracellular formation of advanced glycation end-products, activation of protein kinase $\mathrm{C}$, or overproduction of superoxide by the mitochondrial electron transport chain [44].

Inspite of the significant difference in serum glucose level between type I and type II non-treated diabetic groups in our investigation being higher in type I group, the parameters of oxidative stress and dyslipidemia were not significantly different between the two groups. this can be explained by insulin resistance; a factor characterizing type II DM and indicated by significantly higher HOMAIR in this group when compared to type I DM group in our investigation. HOMA-IR index of type I diabetic non-treated group showed insignif- 
icant difference when compared to corresponding value in non-diabetic group which was an expected result in this model with sever insulin deficiency and no insulin resistance. Similar results were demonstrated by [45] who reported significant increase in HOMA-IR between non diabetic and n-STZ type II diabetic rats but don't agree with [46] who detected insignificant increase in HOMAIR in the type II diabetic group when compared to the normal one. [47] reported that $\beta$-cell insult is the primary factor responsible for the emergence of moderate to severe hyperglycemia in rats and insulin resistance can develop secondarily. White adipose tissue (WAT) plays a crucial role in energy homeostasis including insulin sensitivity, appetite control, energy balance, immunity, angiogenesis, blood pressure, and lipid metabolism, by secreting a wide range of bioactive proteins termed 'adipokines' [48]. Interestingly, both the excess (obesity) and lack (lipoatrophy) of WAT bring severe metabolic consequences such as insulin resistance, hyper-triacylglycerolemia, diabetes, and fatty liver [49]. Not reported in our investigation but reported by [50], that $\mathrm{n}-\mathrm{STZ}$ developed Low body weight and reduced epididymal (EP) fat mass which may explain insulin resistance in type II DM group.

\section{Vildagliptin-treated groups (type I and type II):}

There was insignificant change in the serum glucose, HbA1c, insulin level and HOMA-IR in type I Vil-treated group when compared to the correlated non-treated group, our results in this group also revealed that Vildagliptin treatment for 30 days in type I diabetic rats produced a significant increase in the level of active GLP-1 when compared to corresponding value in non-treated group. these results coincide with [51] who demonstrated insignificantly decreased blood glucose level following Vildagliptin treatment of type I diabetic rats, but in contrast to our investigation he detected significant increase in serum insulin level in the treated group but this increase was not enough to significantly decrease blood glucose level. In addition, similar results were showed by [52] who reported that chronic administration of Vildagliptin increased fasting plasma levels of GLP-1 and GIP.

In addition, our protocol of treatment improved the diabetes induced dyslipidemia in type I Viltreated group indicated by significantly decreased serum cholesterol, TG, LDL-cholesterol and increased serum HDL-cholesterol in this group when compared to corresponding values in the nontreated group. GLP-1R signaling reduces VLDLTG production rate from liver, reduces hepatic TG content by modulating key enzymes of lipid metabolism in liver, and impairs hepatocyte de novo lipogenesis and $\beta$-oxidation. Apart from these direct effects on lipid metabolism, GLP-1 also reduces atherosclerotic events by inhibiting expression of atherogenic inflammatory mediators, suppressing smooth muscle cell proliferation and stimulating NO production [53]

Similar results were demonstrated by [51] who reported that treatment with vildagliptin decreased the levels of TAGs and total cholesterol, and he explained this reduction by a decrease in the concentration of LDL and VLDL because- in his studythere was no alteration in HDL cholesterol. These results suggest that treatment with vildagliptin improved the lipid profiles. Against our study [9] observed that treatment with vildagliptin was not able to improve the lipid parameters, which can be explained by shorter duration of treatment than our study.

Vildagliptin treatment exerted an anti-oxidative effect indicated by significantly decreased serum MDA and significantly increased serum TAC in type I Vil-treated group when compared to corresponding values in the non-treated group. It has been reported that GLP-1R signaling, directly or via reducing thioredoxin interacting protein expression level, modulates the endoplasmic reticulum and oxidative stress, leading to promotion of $B$ cell adaptation and survival $[\mathbf{5 4 , 5 5}]$. It was reported that DPP-4 inhibitor therapy resulted in a significant increase in urinary cAMP excretion in both nondiabetic and diabetic rats indicating that the expression of GLP-1R was up-regulated in diabetic rats treated with Vildagliptin compared with placebo [56]

30 days of vildagliptin treatment in type II diabetic rats in our investigation improved the glycemic state of these rats indicated by a significant decrease in serum glucose level and HbA1c which can be explained by lower insulin resistance and improved $\beta$-cell function induced by our protocol of treatment and indicated by the significant decrease of HOMA- IR and increased serum insulin level respectively in type II Vil-treated group when compared to corresponding values in the correlated non-treated group. Improvement of the two previously mentioned parameters can be explained in our investigation by the significant increase of plasma active GLP-1 levels detected in the treated group when compared to corresponding value in the correlated non-treated group. These results agree with [57] who explained anti-diabetic hypoglycemic effect of Vildagliptin by improved insulin secretion and peripheral insulin sensitivity through binding covalently to the catalytic site of 
DPP-4, eliciting prolonged enzyme inhibition. This raises intact GLP-1 levels, both after meal ingestion and in the fasting state reducing glycemia in patients with type II diabetes mellitus, with a low risk for hypoglycemia and no weight gain. Relevant studies which used experimental models of type II diabetes with or without associated obesity demonstrated that vildagliptin increases pancreatic $\beta$-cell mass by directly enhancing cell differentiation / proliferation [58-59]. Also coinciding with our finding [60] demonstrated that Vildagliptin treatment of type II daibetic patients decreased $\mathrm{HbA} 1 \mathrm{c}$ level. [11] studied the effect of chronic Vildagliptin treatment as a DPP-4 inhibitor on n-STZ induced type II diabetic rats (our model) revealing a dose dependent decrease in blood glucose level and significant increase in plasma GLP-1 and insulin level. [61] and [62] also demonstrated that vildagliptin augment intact GLP-1level in type II DM. [11] observed that vildagliptin treated diabetic rats showed 10.68 folds increase GLP-1R mRNA concentration in the pancreatic $\beta$-cells than diabetic animals. And that the stimulating action of vildagliptin on GLUT2 and GLUT4 expression, mRNA or protein, could be a mechanism by which, at least in part, the DPP-4 inhibitors exerts its lowering effect on blood glucose.

The improved glycemic state and elevated plasma active GLP-1 levels can explain the antioxidative stress benefit induced by vildagliptin treatment and indicated by a significantly decreased serum MDA levels and significantly increased serum TAC levels in type II vil- treated group when compared to corresponding values in the correlated non-treated group.

In addition to the previously mentioned findings Vildagliptin-treatment improved diabetes induced dyslipidemia in our investigation indicated by significantly lower serum cholesterol, TAGs, LDLcholesterol and significantly higher HDL cholesterol in type II Vil-treated group when compared to corresponding values in the correlated nontreated group. Similar results were also reported by [42] whose study demonstrated that Vildagliptin significantly decreased serum cholesterol and LDLcholesterol while significantly increased serum HDL-cholesterol, but in contrast to our study he showed insignificantly changed plasma glucose and TG a difference which can be explained by studying a different obese-insulin resistant rats model. But he demonstrated that Vildagliptin reduced oxidative stress in that model. Sterolregulatory-element-binding proteins (SREBPs) regulate the transcription of genes involved in cholesterol and fatty acid metabolism [63]. The effects of insulin on SREBP-1c have been corroborated by in vivo studies showing that SREBP-1c expression and nuclear abundance were low in the liver of streptozotocin-induced diabetic rats, and markedly increased after insulin treatment [64] The stimulating action of vildagliptin on SREBP$1 \mathrm{c}$ mRNA concentration might be due insulin secretogogue effect; and decreasing insulin resistance.

\section{References}

1- GUPTA A., SHARMA M. and SHARMA J.: A Role of Insulin in different types of Diabetes. Int. J. Curr. Microbiol. App. Sci., 4 (1): 58-77, 2015.

2- DOKKEN B.B.: The Pathophysiology of Cardiovascular Disease and Diabetes: Beyond Blood Pressure and Lipids. Diabetes Spectrum, 21: 160-165, 2008.

3- BULUM T., KOLARIC B., PRKACIN I. and DUVNJAK L.: Total and LDL cholesterol are associated with glomerular filtration rate in normoalbuminuric type 1 diabetic patients. Coll. Antropol., 37 (3): 771-776, 2013.

4- FLAMMER A.J. and LUSCHER T.F.: Three decades of endothelium research: From the detection of nitric oxide to the everyday implementation of endothelial function measurements in cardiovascular diseases. Swiss Medical Weekly, 141: 3-8, 2010.

5- KIM S.J., NIAN C. and WIDENMAIER S.: Glucosedependent insulinotropic polypeptide (GIP) mediated upregulation of b-cell antiapoptotic $\mathrm{Bcl}-2$ gene expression is coordinated by cAMP-response element binding protein (CREB) and cAMP-responsive CREB coactivator 2 (TORC2). Mol. Cell. Biol., 28: 1644-1656, 2008.

6- COX M.A., ROWEL J., CORSINO L. and GREEN J.B.: Dipeptidyl peptidase-4 inhibitors in the management of type 2 diabetes: Safety, tolerability, and efficacy Drug, Healthcare and Patient Safety, 2: 7-19, 2010.

7- GREEN B.D, FLATT P. and BAILEY C.: Dipeptidyl peptidase IV (DPP IV) inhibitors: A newly emerging drug class for the treatment of type 2 diabetes. Diabetes Vas Dis Res., 3 (3): 159-165, 2006.

8- KOZLOVSKI P., FOLEY J., SHAO Q., LUKASHEVICH V. and KOTHNY W.: Vildagliptin-insulin combination improves glycemic control in Asians with type 2 diabetes. World J. Diabetes, 4 (4): 151-156, 2013.

9- MAEDA S., MATSUI T. and YAMAGISHI S.: Vildagliptin inhibits oxidative stress and vascular damage in streptozotocin-induced diabetic rats. Int. J. Cardiol., 158 (1): 171-3, 2012.

10- AVILA D D.L., DE ARA-UJO G.R., SILVA M., MIRANDA PHDA., DINIZ M.F., PEDROSA M.L., SILVA M.E., DE LIMA W.G. and COSTAA D.C.: Vildagliptin Ameliorates Oxidative Stress and Pancreatic Beta Cell Destruction in Type 1 Diabetic Rats. Archives of Medical Research, 44: 194-202, 2013.

11- AKARTE A.S., SRINIVASAN B.P. and GANDHI S.: Vildagliptin selectively ameliorates GLP-1, GLUT4, SREBP-1c mRNA levels and stimulates $\beta$-Cell proliferation resulting in improved glucose homeostasis in rats 
with streptozotocin-induced diabetes, Journal of Diabetes and Its Complications, 26: 266-274, 2012.

12- TRINDER P.: Determination of blood glucose using an oxidase-peroxidase system with a non-carcinogenic chromogen. Am. Clin. Biochem., 22-158: 161, 1969.

13- JUDZEWITSCH R., PFEIFER M., BEST J., HALTER J. and PORT D.: Chronic chlorpropamide therapy of noninsulin dependent diabetes augments and stimulated insulin secretion by increasing islet sensitivity to glucose. J. Clin. Endocrinol. Metab., 55: 321-328, 1982.

14- TRIVELLI L.A., RANNEY H.M. and LAI H.T.: Hemoglobin components in patients with diabetes mellitus. New Engl. J. Med., 284: 353, 1971.

15- MANNUCCI E., OGNIBENE A., CREMASCO F., BARDINI G., MENCUCCI A., PIERAZZUOLI E., CIANI S., FANELLI A., MESSERI G. and ROTELLA C.M.: Glucagon-like peptide (GLP)-1 and leptin concentrations in obese patients with Type 2 diabetes mellitus. Diabet Med., 17 (10): 713-9, 2000.

16- MEIATTINI F., PRENCIPE L., BARDELLI F., GIANNINI G. and TARLI P.: The 4-hydroxybenzoate/4aminop henazone chromogenic system used in the enzymic determination of serum cholesterol. Clin. Chem., 24 (12): 2161$2165,1978$.

17- FOSSATI T. and PRENCIPE L.: Serum triglycerides determined colorimetrically with an enzyme that produces hydrogen peroxide. Clin. Chem., 28: 2077-2080, 1982.

18- FRIEDWALD W.T, LEVEY R.I. and FRIDRIEKSON D.S.: Estimation of the concentration of LDL-C without the use of preparative ultracentrifuge. Clin. Chem., 18 499-501, 1972.

19- GORDON T., CASTELLI W.P., HJORTLAND M.C., KANNEL WB and DAWBER T.R.: High density lipoprotein as a protective factor against coronary heart disease: The Framingham study. Am. J. Med., 62 (5): 707-714, 1977.

20- SATOH K.: Serum lipid peroxide in cerebrovascular disorders determined by a new colorimetric method. Clinica. Chemica. Acta., 90 (1): 37-43, 1978.

21- OHKAWA H., OHISHI W. and YAGI K.: Assay for lipid peroxides in animal tissues by thiobarbituric acid reaction. Anal. Biochem., 95 (2): 351-358, 1979.

22- KORACEVIC D., KORACEVIC G., DJORDJEVIC V., ANDREJEVIC S. and COSIC V.: Method for the measurement of antioxidant activity in human fluids. J. Clin. Pathol., 54: 356-361, 2001.

23- MATTHEWS D., HOSKER J., RUDENSKI A., NAYLOR B., TREACHER D. and TURNER R.: Homeostasis model assessment: insulin resistance and beta cell function from fasting plasma glucose and insulin concentrations in man. Diabetologia, 28: 412-419, 1985.

24- SCHERMER S.: Rats haemopoietic system in: Blood morphology of laboratory animals. 1st edition, Chap.10, P.112. Pbl. Davis. F.A.Co., Philadelphia, 1968.

25- SCRIDON A., PERIAN1M., MARGINEAN A., FISCA1 C., VANTU1 A., GHERTESCU1 D., CHEVALIER P. and SERBAN R.C.: Wistar rats with long-term streptozotocininduced type 1 diabetes mellitus replicate the most relevant clinical, biochemical, and hematologic features of human diabetes. Revista Română de Medicină de Laborator, 23, 2015.
26- TAKADAA J., MACHADOA M.A., PERESA S.B., BRITOA L.C., BORGES-SILVAA C.N., COSTAB C.E.M., FONSECA-ALANIZA M.H., ANDREOTTIA S. and LIMA F.B.: Neonatal streptozotocin-induced diabetes mellitus: A model of insulin resistance associated with loss of adipose mass. Metabolism Clinical and Experimental, 56: 977-984, 2007.

27- OWU D.U., ORIE N.N., NWOKOCHA C.R., CLAPP L.H. and OSIM E.E.: Comparative Effect of Type 1 and Type 2 Diabetes Mellitus on Vascular Responses of Rat Thoracic Aorta to Potassium Ion Channel Openers. British Journal of Medicine \& Medical Research, 3 (3): 748-759, 2013.

28- LIU S.C., TU Y.K., CHIEN M.N. and CHIEN K.L.: Effect of antidiabetic agents added to metformin on glycaemic control, hypoglycaemia and weight change in patients with type 2 diabetes: A network meta-analysis. Diabetes, Obesity and Metabolism, 14: 810-820, 2012.

29- LUIPPOLD G., BEDENIK J., VOIGT A. and GREMPLER R.: Short- and Longterm Glycemic Control of Streptozotocin-Induced Diabetic Rats Using Different Insulin Preparations. PLOS. One., 11 (6): e0156346., 2016.

30- KULKARNI1 C.P., BODHANKAR S.L., GHULE AE., MOHAN V. and THAKURDESAI P.A.: Antidiabetic activity of trigonella foenumgraecum 1 . seeds extract (ind01) in neonatal streptozotocin-induced (n-stz) rats. Diabetologia Croatica, 41-1, 2012.

31- GREENBAUM C.J., PRIGEON R.L., D'ALESSIO D.A.: Impaired B-cell function, incretin effect, and glucagon suppression in patients with type 1 diabetes who have normal fasting glucose. Diabetes, 51, 2002.

32- ZHANG F., TANG X., CAO H., LÜ Q., LI N., LIU Y., ZHANG X., ZHANG Y., CAO M., WAN J., AN Z. and TONG N.: Impaired secretion of total glucagon-like peptide-1 in people with im-paired fasting glucose combined impaired glucose tolerance. International Journal of Medical Sciences Tertilrlfeiclcieces., 9 (7): 574-581, 2012.

33- CALANNA S., CHRISTENSEN M. and HOLST J.J.: Secretion of glucagon-like peptide-1 in patients with type 2 diabetes mellitus: Systematic review and meta-analyses of clinical studies Diabetologia, 56 (5): 965-972, 2013.

34- WANG X.L., YE F. and LI J.: Impaired secretion of glucagonlike peptide 1 during oral glucose tolerance tes in patients with newly diagnosed type 2 diabetes mellitus. Saudi Medical Journal, 37 (1): 48-54, 2016.

35- BAK M.J., ALBRECHTSEN N.J.W. and PEDERSEN J.: Specificity and sensitivity of commercially available assays for glucagon-like peptide-1 (GLP-1): Implications for GLP-1 measurements in clinical studies. Diabetes, Obesity \& Metabolism, 16 (11): 1155-1164, 2014.

36- NAUCK M.A., VARDARLI I., DEACON C.F., HOLST J.J. and MEIER J.J.: Secretion of glucagon-like peptide1 (GLP-1) in type 2 diabetes: What is up, what is down? Diabetologia, 54 (1): 10-18, 2011.

37- NAUCK M.A. and MEIER J.J.: Incretin hormones: Their role in health and disease. Diabetes. Obes. Metab., 20 (1): 5-21. 2018.

38- YANG D.K. and KANG H.S.: Anti-Diabetic Effect of Cotreatment with Quercetin and Resveratrol in Streptozotocin-Induced Diabetic Rats. Biomol. Ther., 26 (2): 130-138, 2018. 
39- REFAAT R., SAKR A., SALAMA M. and EL-SARHA A.: Combination of Vildagliptin and Pioglitazone in Experimental Type 2 Diabetes in Male Rats. Drug. Development Research, 77 : 300-309, 2016.

40- POCHHI M. and MUDDESHWAR M.G.: Hypoglycemic and antihyperlipidemic effect of aqueous leaves extract of Ficus Religiosa in alloxan induced diabetic rats. Asian Journal of Medical Sciences, 8 (2), 2017.

41- MOHAMMADY I., ELATTAR S., MOHAMMED S. and EWAIS M.: An Evaluation of Anti-Diabetic and AntiLipidemic Properties of Momordica charantia (Bitter Melon) Fruit Extract in Experimentally Induced Diabetes. Life Science Journal, 9 (2): 2012.

42- APAIJAI N., CHINDA K., PALEE S., CHATTIPAKORN S. and CHATTIPAKORN N.: Combined Vildagliptin and Metformin Exert Better Cardioprotection than Monotherapy against Ischemia-Reperfusion Injury in Obese-Insulin Resistant Rats. Plos. One, 9 (7): e102374, 2014.

43- KEITA H., CORONA L.Q., JUAN E.R.S. and CASTRO N.P.: lipoperoxidation and vascular reactivity response in rat models of streptozotocininduced diabetes mellitus. Indo American Journal of Pharmaceutical Sciences, 3 (10), 2016.

44- RAINS J.L. and JAIN S.K.: Oxidative stress, insulin signaling and diabetes. Free. Radic. Biol. Med., 50 (5): 567-575, 2011.

45- SHIRALI S., BABAALI S. and BABAALI H.: A Comparative Study on the Effects of Incretin and Metformin on sugar Profile and Insulin Resistance in STZ-induced Diabetic Wistar Rats. Research Journal of Pharmaceutical, Biological and Chemical Sciences, 7 (5): 1921-1929, 2016.

46- PATIL M.A., SURYANARAYANA P., PUTCHA U.K., SRINIVAS M. and REDDY G.B.: Evaluation of Neonatal Streptozotocin Induced Diabetic Rat Model for the Development of Cataract. Oxidative Medicine and Cellular Longevity, 463264, 2014.

47- ARULMOZHI D.K., VEERANJANEYULU A. and BODHANKAR S.L.: Neonatal streptozotocin-induced rat model of type 2 diabetes mellitus: A glance. Indian Journal of Pharmacology, 36 (4): 217-221, 2004.

48- FISCHER-POSOVSZKY P., WABITSCH M. and HOCHBERG Z.: Endocrinology of Adipose Tissue- 2 An Update. Hormone Metabolic Research, 39 314-21, 2007.

49- GAVRILOVA O., MARCUS-SAMUELS B., GRAHAM D., KIM J.K., SHULMAN G.I., CASTLE A.L., VINSON C., ECKHAUS M. and REITMAN M.L.: Surgical implantation of adipose tissue reverses diabetes in lipoatrophic mice. Journal of Clinical Investigation, 10 (5): 271-8, 2000.

50- TAKADA J., FONSECA-ALANIZ M.H., FERRAZ DE CAMPOS T.B., ANDREOTTI S., CAMPANA1A.B., OKAMOTO M., BORGESSILVA C., MACHADO U.F. and LIMA F.B.: Metabolic recovery of adipose tissue is associated with improvement in insulin resistance in a model of experimental diabetes. Journal of Endocrinology, 198: 51-60, 2008.

51- MIRANDA P.H.dA., MONTEIRO O.M., JOAMYR V. ROSSONI Jr., SILVA M.E., LIMA W.G.D. and COSTA D.C.: Vildagliptin Induces B-Cell Neogenesis and Improves the Lipid Profile in a Later Phase of Type 1
Diabetes. Current Pharmaceutical Biotechnology, 16: 6065, 2015.

52- FOLEY J.E., LIGUEROS-SAYLAN M., HE Y.L., HOLST J.J., DEACON C.F., DUNNING B.E., LEONE-JONES A., YU T. and KELLEY D.E.: Effect of Vildagliptin on Glucagon Concentration During Meals in Patients with Type 1 Diabetes. Horm. Metab. Res., DOI: 10.1055/s1078754, 2008

53- PATEL V.J., JOHARAPURKAR A.A., SHAH G.B. and JAIN M.R.: Effect of GLP-1 Based Therapies on Diabetic Dyslipidemia. Current Diabetes Reviews, 10 (4): 238250, 2014

54- YUSTA B., BAGGIO L.L., ESTALL J.L., KOEHLER J.A., HOLLAND D.P., LI H., PIPELEERS D., LING Z. and DRUCKER D.J.: GLP-1 receptor activation improves B-cell function and survival following induction of endoplasmic reticulum stress. Cell. Metab., 4: 391-406, 2006.

55- YU Z. and JIN T.: New insights into the role of cAMP in the production and function of the incretin hormone glucagon-like peptide-1 (GLP-1). Cell. Signal., 22: 1-8, 2010.

56- LIU W.J., XIE S.H., LIU Y.N., KIM W., JIN H.Y., PARK S.K., SHAO Y.M. and PARK T.S.: Dipeptidyl Peptidase IV Inhibitor Attenuates Kidney Injury in StreptozotocinInduced Diabetic Rats. The Journal of Pharmacology and Experimental Therapeutics, 340: 248-255, 2012.

57- SHARMA A.K., KANAWAT D.S., MISHRA A., DHAKAD P.K., SHARMA P., SRIVASTAVA V., JOSHI S., JOSHI M., RAIKWAR S.K., KURMI M.K. and SRINIVASAN B.P.: Dual therapy of vildagliptin and telmisartan on diabetic nephropathy in experimentally induced type 2 diabetes mellitus rats. Journal of the Renin-AngiotensinAldosterone System, 15 (4): 410-418, 2014.

58- GIAMPIETRO O., GIAMPIETRO C., BARTOLA L.D., MASONI M.C. and MATTEUCCI E.: Sitagliptin as addon therapy in insulin deficiency: Biomarkers of therapeutic efficacy respond differently in type 1 and type 2 diabetes. Drug Des. Devel. Ther., 7: 99-104, 2013.

59- OMAR B.A., VIKMAN J., WINZELL M.S., VOSS U., EKBLAD E., FOLEY J.E. and AHRÉN B.: Enhanced beta cell function and anti-inflammatory effect after chronic treatment with the dipeptidyl peptidase- 4 inhibitor vildagliptin in an advanced-aged diet-induced obesity mouse model. Diabetologia, 6 (8): 1752-1760, 2013.

60- PI-SUNYER F.X., SCHWEIZER A., MILLS D. and DEJAGER S.: Efficacy and tolerability of vildagliptin monotherapy in drug-naive patients with type 2 diabetes. Diabetes. Res. Clin. Pract., 76: 132-138, 2007.

61- D'ALESSIO D.A., DENNEY M.A., HERMILLERL.M., PRIGEON R.L., MARTIN J.M., THARP W.G., SAYLAN M.L., HE Y., DUNNING B.E., FOLEY J.E. and PRATLEY R.E.: Treatment with the Dipeptidyl Peptidase-4 Inhibitor Vildagliptin Improves Fasting Islet-Cell Function in Subjects with Type 2 Diabetes. J. Clin. Endocrinol. Metab., 94: 81-88, 2009.

62- PINTANA H., APAIJAI N., CHATTIPAKORN N. and CHATTIPAKORN S.C.: DPP-4 inhibitors improve cognition and brain mitochondrial function of insulin-resistant rats. Journal of Endocrinology, 218: 1-11, 2013. 
63- GANG X., HIDEAKI K.D., ROSS L., VALERIE F., DUVIVIER K. and NITIN T.: Downregulation of GLP1 and GIP Receptor Expression by Hyperglycemia Possible Contribution to Impaired Incretin Effects in Diabetes. Diabetes, 56: 1551-1558, 2007.
64- VALERIO A., CARDILE A., COZZI V., BRACALE R. TEDESCO L. and PISCONTI A.: TNF-alpha downregulates eNOS expression and mitochondrial biogenesis in fat and muscle of obese rodents. The Journal of Clinical Investigation, 116: 2791-2798, 2006.

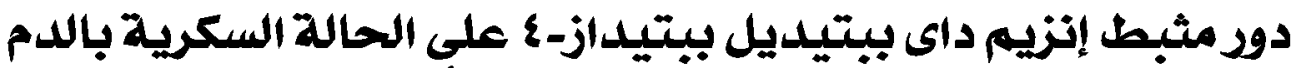

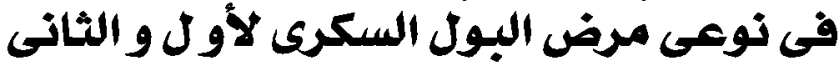 في فئران - دراسة مقاسيكري لاون}

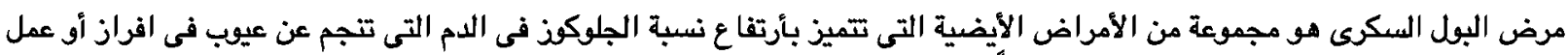

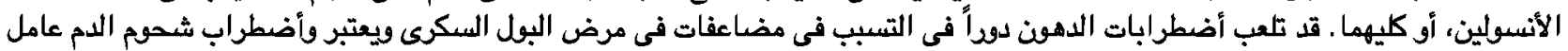

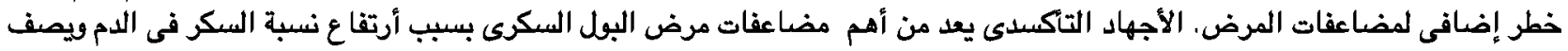

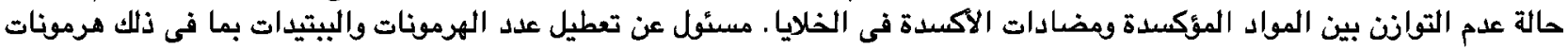



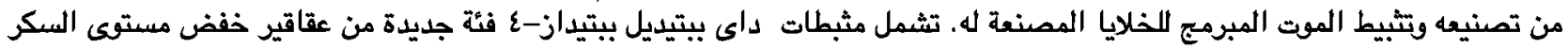

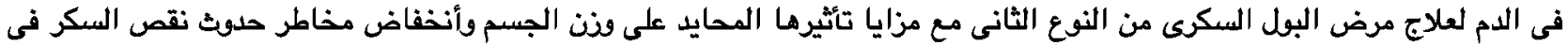

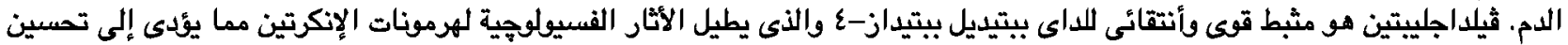

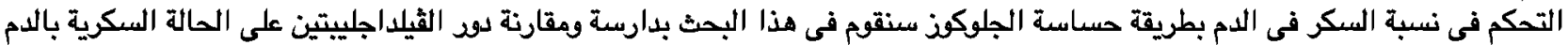
فى النوع الأول والنوع الثانى من داء البول السكرى في الفئر الفئران.

مواد وطرق البحث: تم إجراء هذه الدراسة على خمسين من ذكور الفئران اليضاء التهاء التى تعيش فى أقفاص جيدة التهوية فى درجة حرارة

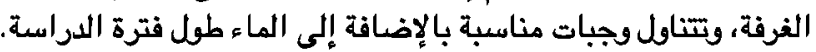

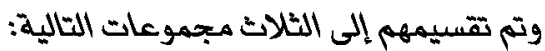

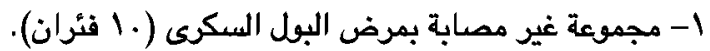

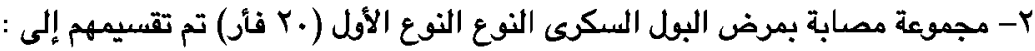

أ - مجموعة مصابة بمرض البول السكرى النوع الأول بدن معالجة (لالبكل (الفئران).

ب- مجموعة مصابة بمرض البول السكرى النوع الأول ومعالجة بالثيلداجلييتين (· الفئران).

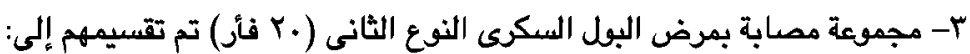

أ - مجموعة مصابة بمرض البول السكرى النوع الثانى بلون معالجة (.افئران).

ب- مجموعة مصابة بمرض البول السكرى النوع الثانى ومعالجة بالثيلداجليتينين (.افئران).

وتم فى نهاية هذا البحث تصويم الفئران طول الليل ثم ستب عينات دم من خلف العين لقياس:

1- دستوى الهيموجلوبين السكرى فى الدم ومستوى الجلوكاجون البيتيدى الأول فى البلازما ومستوى الجلوكوذ والأنسولين فى السيروم.

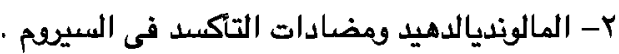

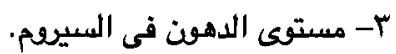

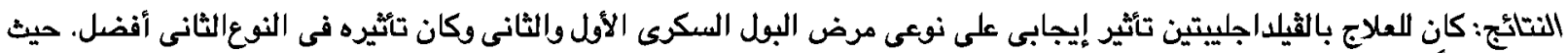

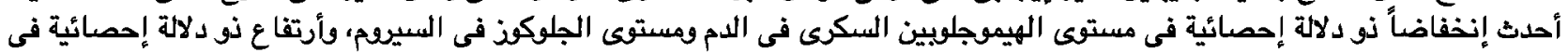

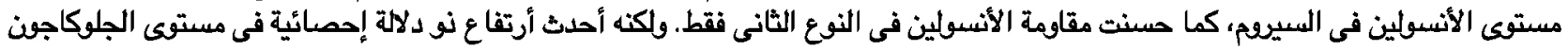

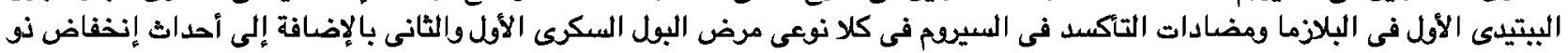

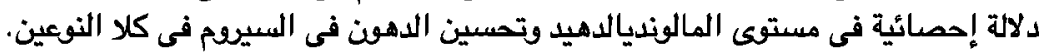

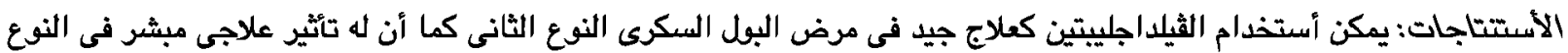
الأفل. ومع ذلك لابد من أجراء المزيد من الأبحاث لتاكيد هذه النتائج. 